\title{
Acetabular Reconstruction with Massive Allograft Shaped to the Cavity and Kerboull-Type Acetabular Reinforcement Device for Multiple Failures of Impaction Bone Graft: A Case Report
}

\author{
Takaya Taniguchi, Mayumi Sonekatsu, Wataru Taniguchi*, Erabu Miyamoto, Takahide Sasaki, \\ Munehito Yoshida
}

Department of Orthopaedic Surgery, Wakayama Medical University, Wakayama, Japan

Email: ^twataru@wakayama-med.ac.jp

How to cite this paper: Taniguchi, T., Sonekatsu, M., Taniguchi, W., Miyamoto, E., Sasaki, T. and Yoshida, M. (2017) Acetabular Reconstruction with Massive Allograft Shaped to the Cavity and KerboullType Acetabular Reinforcement Device for Multiple Failures of Impaction Bone Graft: A Case Report. Open Journal of Orthopedics, 7, 14-20.

http://dx.doi.org/10.4236/ojo.2017.71003

Received: December 13, 2016

Accepted: January 19, 2017

Published: January 22, 2017

Copyright $\odot 2017$ by authors and Scientific Research Publishing Inc. This work is licensed under the Creative Commons Attribution International License (CC BY 4.0).

http://creativecommons.org/licenses/by/4.0/

\begin{abstract}
Acetabular component revision in the presence of severe bone loss is difficult for reconstructing an acetabular component in the anatomical hip center. Various treatment options are available, although often the acetabular defect cannot be corrected with a single option alone. Precise assessment of the bone loss and a suitable combination of methods are needed. Here we report a case of multiple failures with impaction bone grafting reconstruction for an acetabular bone defect of American Academy of Orthopedic Surgeons classification type III. We finally reconstructed the acetabulum with three femoral head allografts and a Kerboull-type acetabular reinforcement device. The allograft was a casted, jet-type helmet-like shape. A year later the patient was able to walk without a cane and perform light agricultural work. Accurate evaluation of the acetabular bone loss and appropriate reconstruction is important.
\end{abstract}

\section{Keywords}

Acetabular Reconstruction, Bone Defect, Allograft, KT Plate, Impaction Bone Graft

\section{Introduction}

One of the most difficult problems during acetabular reconstruction is the management of a large bone defect. An appropriate bone graft with augmentation is required for secure reconstruction. Several techniques are used to manage such a 
defect, including placement of a jumbo cup [1], specialized roof and reconstruction rings [2], modular porous metal augmentation [3], or bulk or morselized cancellous bone grafts [4] [5]. A combination of these methods may also be considered. The use of morselized cancellous bone graft and a cementless porous coated acetabular component is also a well-established acetabular revision surgical technique in the presence of bone deficiency [6] [7]. These options are often inadequate, however, when the acetabular bone loss is great. Here, we report a patient with a difficult revision total hip arthroplasty (THA) who had cup migration and an acetabular large bone defect after several cup revisions performed with an impaction bone grafting (IBG) technique. We finally performed a successful reconstruction with a massive allograft and a Kerboull-type acetabular reinforcement device.

\section{Case Report}

An 81-year-old man with a body mass index of $27.6 \mathrm{~kg} / \mathrm{m}^{2}$ had undergone left THA for osteoarthritis of his left hip joint in 1998 (Figure 1(a)) by the posterior approach at another hospital. Seven years later, cup revision with a Ganz reinforcement ring and artificial bone was performed for aseptic loosening (Figure $1(b)$ ). Nine years after the cup revision, he complained of left hip pain. Plain radiography showed that the Ganz reinforcement ring had dislocated (Figure 1(c)). Cup re-revision with rim mesh from superolateral to posterior of the acetabulum and IBG were performed (Figure 1(d)). The cup dislocated again within a few months (Figure 1(e)), and a third cup revision with IBG and mesh was performed (Figure 1(f)). The cup shortly dislocated again (Figure 2(a)), and the patient was referred to our hospital. At the first visit to our hospital, computed tomography (CT) revealed an American Academy of Orthopedic Surgeons (AAOS) type III acetabular defect (Figure 2(b), Figure 2(c)) [8]. Laboratory tests showed the following: white blood cell count $8900 / \mu \mathrm{L}, \mathrm{C}$-reactive protein $1.4 \mathrm{mg} / \mathrm{dL}$, and joint fluid culture negative for infection. Bone scintigraphy, early phase, did not show significant uptake of $99 \mathrm{mTc}$-hydroxymethylene diphosphonate. Because it was possible that we would have to exfoliate and reconstruct the posterior supporting tissue, preoperative left internal iliac arterial branch embolization was performed to control bleeding. Acetabular reconstruction was then implemented with an allograft and the Kerboull-type acetabular reinforcement device (K-MAX KT plate S ${ }^{\oplus}$, 48-15-15; Kyocera Medical, Kyoto, Japan) (Figure 3(a), Figure 3(b)). To avoid nerve palsy, the operation was done under monitoring with muscle evoked potentials after electric stimulation of the brain [Br(E)-MsEP].

The posterior approach was adapted to view the acetabular components under the general anesthesia. First, we placed a bowl-shaped femoral head allograft into the floor of the acetabulum, followed by other trimmed allografts at the anterior and posterior walls and superior of the floor of the acetabulum. The shape of the composed allograft was like that of a jet-type helmet from three femoral head allografts (Figure 4). The anterior, posterior, and superior allografts were fixed 
using absorbable screws. The K-MAX KT plate $S^{\circledast} 48-15-15$ and EXETER X3Rimfit cup (size 48 - 32; Stryker, Kalamazoo, MI, USA) were set using antibiotic-loaded acrylic cement, which was composed of $0.6 \mathrm{~g}$ amikacin and $1.5 \mathrm{~g}$ vancomycin per $40 \mathrm{~g}$ cement. We carefully hooked the KT plate onto the obturator foramen and set three metal screws via the palette of the KT plate. There was no nerve palsyafter surgery and no significant change in the $\mathrm{Br}(\mathrm{E})$-MsEP amplitude during any of the intraoperative periods, although the leg lengthening was $1.5 \mathrm{~cm}$. There was also no neutrophil invasion to the tissues during the intraoperative rapid pathological diagnosis. Tricortical fixation of three metal screws was confirmed on the postoperative CT scan (Figure 3(c)). There was no
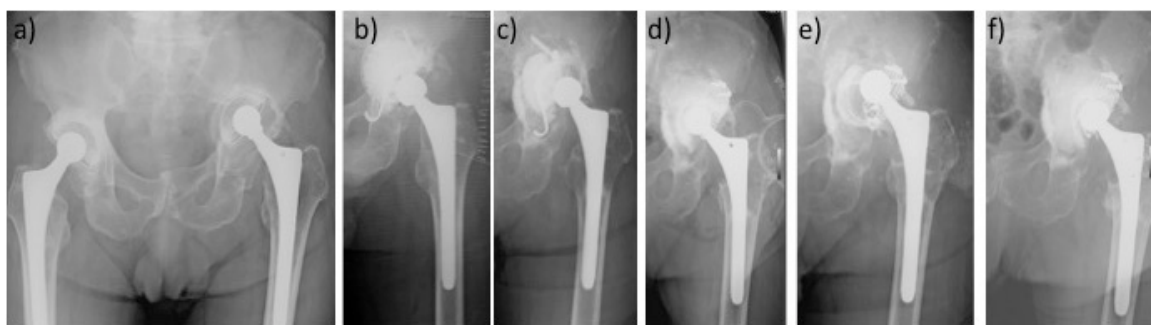

Figure 1. Radiographs, pelvic anteroposterior (AP) view. (a) Primary total hip arthroplasty. (b) First cup revision for aseptic loosening (7 years after a). (c) Ganz reinforcement ring dislocation (9 years after b). (d) Second cup with rim mesh impaction bone grafting (IBG). (e) Third cup dislocation (a few months after d). (f) Final IBG cup revision.
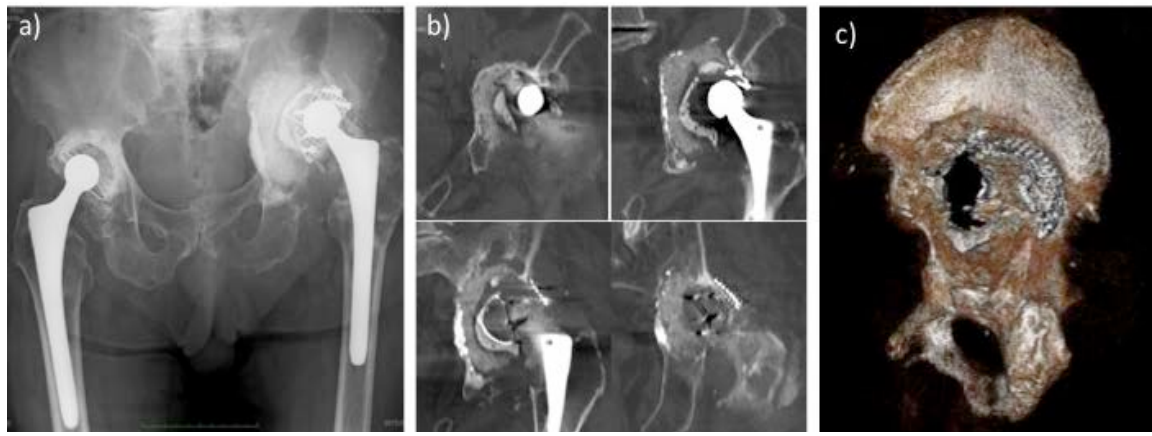

Figure 2. Imaging findings at the first visit to our hospital. (a) Radiography, pelvic AP view, at the first visit. (b) Computed tomography (CT) scan of the left hip at the first visit. (c) Three-dimensional CT findings.
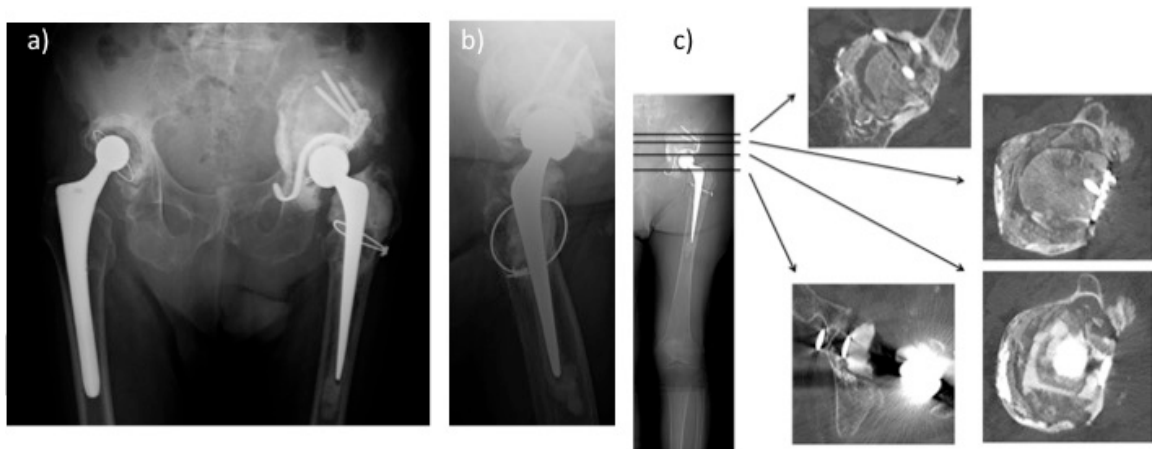

Figure 3. Postoperative findings. (a) Radiography, pelvic AP view. (b) Radiography, lateral view of the left hip. (c) Postoperative CT scan. 


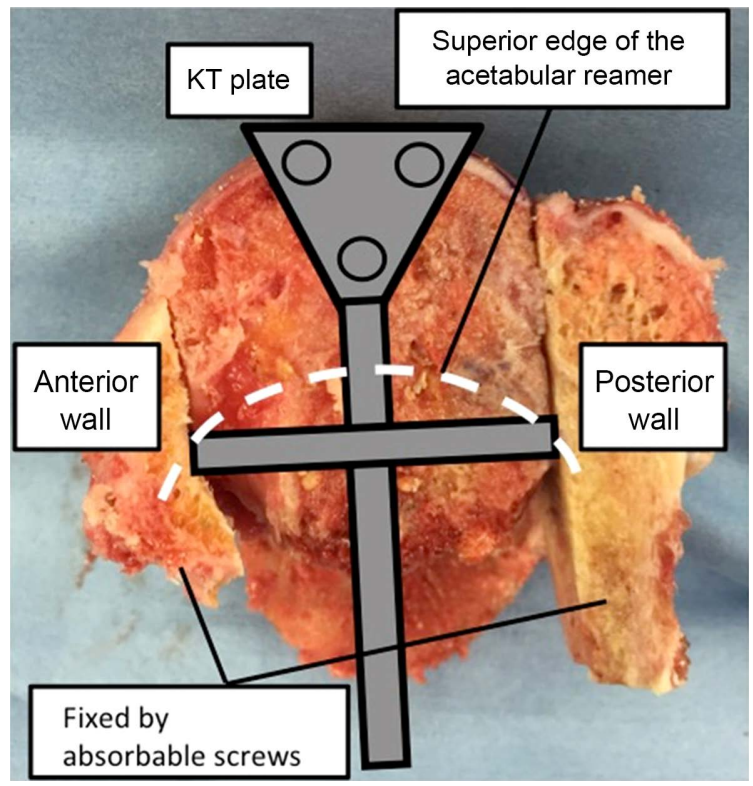

Figure 4. Jet-type helmet-like allograft that we created.

allergic reaction of allograft bone after the surgery. The Harris hip score was 81 at the final follow-up, which was an improvement from the score of 15 prior to the surgery.

In addition, although the intraoperative rapid pathological diagnosis was negative for infection, we infused daptomycin and minocycline for 4 weeks following the operation because of the possibility of low-grade infection. He remained at bed rest for 2 weeks postoperatively and then was permitted full weight bearing at 6 weeks. As he had experienced a posterior dislocation on postoperative day 40 , he was discharged from the hospital wearing a hip protector. Although an incorporation of grafted bone is incomplete at 1 year after the operation, he walks without any brace or cane, and no other dislocation has occurred.

\section{Discussion}

In this case, the patient had AAOS type III acetabular bone defect, although radiological assessment of bone defect is difficult after IBG with cement acetabular revision. Prior to his being referred to our hospital, he had undergone IBG acetabular revision twice within a short span of time. The use of IBG is widely accepted because it works like living bone and provides good implant stability and function [9]. Several studies reported good long-term or mid-term clinical results of acetabular revision with the IBG technique [10] [11]. It has been suggested, however, that IBG is not good indication for severe bone defects of the acetabulum. Iwase et al. showed that acetabular IBG reconstruction was indicated in cases in which the maximum acetabular defect distance was within 20 $\mathrm{mm}$ and the problem was a simple wall defect [12]. They suggested using a reinforcement ring or a cage with bulk allograft [13] [14] or porous trabecular metal auguments [6] [7] with IBG for cases with $>20 \mathrm{~mm}$ maximum acetabular defect distance combined with multiple segmental wall defects [12]. Van Haaren et al. 
also reported a high failure rate of IBG for large acetabular defects such as an AAOS type III or IV bone defect [15].

The main causes of the present patient's IBG collapse could be as follows: 1) A large defect was treated with only IBG and rim mesh. 2) The acetabular floor was fragile because artificial bone was used. 3) There might have been a low-grade infection. Hence, we used massive bulk allografts casted like a jet-type helmet and a Kerboull-type acetabular reinforcement device. Using bulk allograft is recommended for large acetabular defects [12] [16]. This method was developed for long-term storage of bacteriologically safe and biologically suitable bone grafts [17] [18]. Advantages of the allograft are that there is no limitation to its size or shape, and there is no donor site morbidity. Moreover, the Kerboull-type acetabular reinforcement device is able to provide the hip with an appropriate center of rotation and is often used with bulk grafts for large acetabular bone defects because of satisfactory mid-term results following revision THA [14] [19]. In this case, we reconstructed the acetabulum with KT plate and three femoral head allografts, which were shaped like jet-type helmet. Although the follow up period is short, he can walk without any brace or cane now, so the degree of his satisfaction is high.

\section{Conclusion}

In this case, the patient is making satisfactory progress with the uniquely shaped bulk allograft compensating for the large bone defect. Although we will check him frequently over a long period, this case represents a good result during the short-term period.

\section{Consent}

The authors obtained consent for the publication from the patient and family.

\section{Conflicts of Interest}

The authors declare that there is no conflict of interest regarding the publication of this paper.

\section{References}

[1] Whaley, A.L., Berry, D.J. and Harmsen, W.S. (2001) Extra-Large Uncemented Hemispherical Acetabular Components for Revision Total Hip Arthroplasty. Journal of Bone and Joint Surgery-American Volume, 83, 1352-1357. https://doi.org/10.2106/00004623-200109000-00010

[2] Dennis, D.A. (2003) Management of Massive Acetabular Defects in Revision Total Hip Arthroplasty. Journal of Arthroplasty, 18, 121-125. https://doi.org/10.1054/arth.2003.50105

[3] Abolghasemian, M., Tangsataporn, S., Sternheim, A., Backstein,D.J., Safir, O.A. and Gross, A.E. (2013) Porous Metal Augments: Big Hopes for Big Holes. The Bone \& Joint Journal, 95, 103-108. https://doi.org/10.1302/0301-620X.95B.32907

[4] Oakes, D.A. and Cabanela, M.E. (2006) Impaction Bone Grafting for Revision Hip Arthroplasty: Biology and Clinical Applications. Journal of the American Academy 
of Orthopaedic Surgeons, 14, 620-628.

https://doi.org/10.5435/00124635-200610000-00004

[5] Etienne, G., Bezwada, H.P., Hungerford, D.S. and Mont, M.A. (2004) The Incorporation of Morselized Bone Grafts in Cementless Acetabular Revisions. Clinical Orthopaedics and Related Research, 428, 241-246.

[6] Borland, W.S., Bhattacharya, R., Holland, J.P. and Brewster, N.T. (2012) Use of Porous Trabecular Metal Augments with Impaction Bone Grafting in Management of Acetabular Bone Loss. Early to Medium-Term Results. Acta Orthopaedica, 83, 347-352. https://doi.org/10.3109/17453674.2012.718518

[7] Gill, K., Wilson,M.J., Whitehouse, S.L. and Timperley, A.J. (2013) Results Using Trabecular Metal ${ }^{\mathrm{T}}$ Augments in Combination with Acetabular Impaction Bone Grafting in Deficient Acetabula. Hip International, 23, 522-528.

https://doi.org/10.5301/hipint.5000053

[8] D’Antonio, J.A., Capello, W.N., Borden, L.S., Bargar, W.L., Bierbaum, B.F., Boettcher, W.G., et al. (1989) Classification and Management of Acetabular Abnormalities in Total Hip Arthroplasty. Clinical Orthopaedics and Related Research, 243, 126-137.

[9] Schimmel, J.W., Buma, P., Versleyen, D., Huiskes, R. and Slooff, T.J. (1998) Acetabular Reconstruction with Impacted Morselized Cancellous Allografts in Cemented Hip Arthroplasty. Journal of Arthroplasty, 13, 438-448. https://doi.org/10.1016/S0883-5403(98)90010-9

[10] Schreurs, B.W., Keurentjes, J.C., Gardeniers, J.W., Verdonschot, N., Slooff, T.J. and Veth, R.P. (2009) Acetabular Revision with Impacted Morsellised Cancellous Bone Grafting and a Cemented Acetabular Component. A 20- to 25-Year Follow-Up. Journal of Bone and Joint Surgery-British Volume, 91, 1148-1153. https://doi.org/10.1302/0301-620X.91B9.21750

[11] Comba, F., Buttaro, M., Pusso, R. and Piccaluga, F. (2006) Acetabular Reconstruction with Impacted Bone Allografts and Cemented Acetabular Components: A 2- to 13-Year Follow-Up Study of 142 Aseptic Revisions. Journal of Bone and Joint Surgery-British Volume, 88, 865-869. https://doi.org/10.1302/0301-620X.88B7.17227

[12] Iwase, T., Ito, T. and Morita, D. (2014) Massive Bone Defect Compromises Postoperative Cup Survivorship of Acetabular Revision Hip Arthroplasty with Impaction Bone Grafting. Journal of Arthroplasty, 29, 2424-2429.

https://doi.org/10.1016/j.arth.2014.04.001

[13] Kerboull, M., Hamadouche, M. and Kerboull, L. (2000) The Kerboull Acetabular Reinforcement Device in Major Acetabular Reconstructions. Clinical Orthopaedics and Related Research, 378, 155-168.

https://doi.org/10.1097/00003086-200009000-00025

[14] Kawanabe, K., Akiyama, H., Onishi, E. and Nakamura, T. (2007) Revision Total Hip Replacement Using the Kerboull Acetabular Reinforcement Device with Morsellised or Bulk Graft. Results at a Mean Follow-Up of 8.7 Years. Journal of Bone and Joint Surgery-British Volume, 89, 26-31. https://doi.org/10.1302/0301-620X.89B1.18037

[15] Van Haaren, E.H., Heyligers, I.C., Alexander, F.G. and Wuisman, P.I. (2007) High Rate of Failure of Impaction Grafting in Large Acetabular Defects. Journal of Bone and Joint Surgery-British Volume, 89, 296-300. https://doi.org/10.1302/0301-620X.89B3.18080

[16] Somers, J.F., Timperley, A.J., Norton, M., Taylor, R. and Gie, G.A. (2002) Block Allografts in Revision Total Hip Arthroplasty. Journal of Arthroplasty, 17, 562-568. https://doi.org/10.1054/arth.2002.33271

[17] Burchardt, H. (1983) The Biology of Bone Graft Repair. Clinical Orthopaedics and 
Related Research, 174, 28-42. https://doi.org/10.1097/00003086-198304000-00005

[18] Tomford, W.W., Doppelt, S.H., Mankin, H.J. and Friedlaender, G.E. (1983) 1983 Bone Bank Procedures. Clinical Orthopaedics and Related Research, 174, 15-21. https://doi.org/10.1097/00003086-198304000-00003

[19] Hori, J., Yasunaga, Y., Yamasaki, T., Yoshida, T., Oshima, S., Yamasaki, K., et al. (2012) Mid-Term Results of Acetabular Reconstruction Using a Kerboull-Type Acetabular Reinforcement Device. International Orthopaedics, 36, 23-26. https://doi.org/10.1007/s00264-011-1248-0

Submit or recommend next manuscript to SCIRP and we will provide best service for you:

Accepting pre-submission inquiries through Email, Facebook, LinkedIn, Twitter, etc. A wide selection of journals (inclusive of 9 subjects, more than 200 journals) Providing 24-hour high-quality service User-friendly online submission system Fair and swift peer-review system Efficient typesetting and proofreading procedure Display of the result of downloads and visits, as well as the number of cited articles Maximum dissemination of your research work

Submit your manuscript at: http://papersubmission.scirp.org/

Or contact ojo@scirp.org 